\title{
GARNISHMENT OF PUBLIC EMPLOYEES*
}

\author{
CARI R. LichtensteIn $\dagger$
}

\section{F}

THE Massachusetts court speaking:

"The consequence of this opinion is, that a publick officer, who

1 has money in his hands to satisfy a demand, which one has upon him merely as publick officer, cannot for that cause be adjudged his trustee." Thus, in I8Ix, was enunciated our rule exempting public employees from the process of garnishment.

A contrary decision would be mischievous [the court went on], as will appear from this single consideration - that it would suspend, during the pendency of an action, a possibility of settling the accounts of the officer, who should be summoned as his trustee; and it may be added, that it would unreasonably compel him to attend courts in every county in the commonwealth, to answer interrogatories. ${ }^{2}$.

This opinion, rendered in the case of Chealy $v$. Brewer, ${ }^{3}$ concerned an attempt to attach the funds due a juror to pay his debts, by citing the town treasurer to appear in court as trustee for the attaching creditor. The trustee's refusal to appear was thus upheld. In I846 the United States Supreme Court followed up this decision in the case of a seaman in the American navy whose pay was sought to be attached. Justice McLean there said:

If the creditors of these seamen may, by process of attachment, divert the public money from its legitimate and appropriate object, the same thing may be done as regards the pay of our officers and men of the army and of the navy; and also in every other case where the public funds may be placed in the hands of an agent for disbursement. To state such a principle is to refute it. No government can sanction it. At all times it would be found embarrassing, and under some circumstances it might be fatal to the public service. 4

Within a comparatively short time it was already a general though not universal rule of the common law that garnishment process could not be used against officers and employees of governmental bodies. Apparently the legislatures had not expressed any intention of exempting anyone from the operation of their garnishment statutes. Yet the courts have held that a municipal corporation does not come within the designation of any person or persons whatever, corporate or sole, as persons liable to garnishment; nor does the designation "corporation" include municipal corporations for this purpose, according to some authorities, though there are

* A table of relevant statutes is printed at the end of this article.

$\uparrow$ Member of the Illinois bar. I Chealy v. Brewer, 7 Mass. 259, 26r (I8II).

I Ibid. ${ }^{3} 7$ Mass. 259 (I8II). 4 Buchanan v. Alexander, 4 How. (U.S.) 20 (I846). 
decisions to the contrary.5 At present, however, several states have enacted statutes prohibiting the garnishment of public employees: Iowa, ${ }^{6}$ Massachusetts, ${ }^{7}$ Pennsylvania, ${ }^{8}$ and Texas. ${ }^{9}$ Pennsylvania's statute dates back to 1845 .

Typical of the trend of opinion in the nineteenth century is the line of authority in Mlinois. The Mllinois statute is silent on the exemption of municipal or public bodies from its garnishment act. In the first case of its kind the Illinois Supreme Court held that the garnishment of municipal corporations

must be decided as a question of public policy. ... To permit the great public duties of this corporation to be imperfectly performed, in order that individuals may the better collect their private debts, would be to pervert the great objects of its creation. ${ }^{\text {Io }}$

This case was later re-affirmed on the suit of a judgment creditor of a police officer against a city treasurer, in Triebel v. Colburn..$^{\text {II }}$ After disposing of the question of public policy, the court made the following additional observation:

The city treasurer in this case had no money of the judgment debtor, the policeman, in his hands; the money due to the latter, for his salary, did not become his money until paid over to him. . . . He could not have maintained an action against the treasurer . . . . but would have been compelled to sue the city which alone was as his debtor. ${ }^{12}$

Though this case was decided in 1872 , it contains the last word of the Tllinois courts on this subject. A statute passed in 1905 to correct this condition was declared unconstitutional because of various defects in its drafting. ${ }^{.3}$

The reasons advanced by the courts for exempting governmental employees from garnishment may be summarized as follows:

I. Garnishment is not in the nature of an execution but more like a civil suit of the kind where the state may insist on its sovereign immunity from being sued by its citizens except in the form authorized by its legislature.

2. Since an officer holds funds in his hands in his legal capacity, he is the owner of such funds as against even the governmental employee, even though the latter may be entitled to receive a certain specified portion thereof for his services. Suing said officer would be indirectly suing the public body, which is not permitted.

3. Public policy forbids it. As one court expressed the rule: "The exemption is granted from public necessity, in order that the business of the

5 Switzer v. Wellington, 40 Kan. 250, I9 Pac. 620 (I888); Ann. Cas. r9r3B, 746, note.

${ }^{6}$ Code I927, § I2I59.

${ }^{8}$ Purdon's Penn. Stat. Ann. r931, \$886.

7 G. I. 2992 , Ch. $246, \$ 32$ (3).

9 Tex. Comp. Stat. rg28, § II75.

10 Merwin v. Chicago, 45 Ill. I33, I35 (I867). II 64 Ill. 376 (I872). $\quad$ I2 Ibid., 378.

I3 Badenoch v. Chicago, 222 Ill. 7 I, 78 N.E. 3 I (Igo6). 
municipality may be transacted by its officers without interference arising from suits in which the public is not interested." ${ }^{4}$

These reasons are impressive, and are entitled to serious consideration. But set an impartial onlooker to study them, and some doubt may creep into his mind. He may think it strange that for the purpose of garnishment of public employees, an officer acts only as the representative of the public body with which he is associated, while for the purpose of testing the constitutionality of a statute this same public officer may be sued as a private individual, even though he may justify his deeds under authority of an act of the legislature. This impartial student may also wonder at the artificial distinction in the holding that an employee has such an interest in the funds of the state due him that he may maintain an action for them in the case of municipal corporations, and may have a good claim to the legislature, in the case of a state, and yet this interest is not such as to be subject to attachment by his creditors. And as for public policy, our unbiased friend finds himself in a bewildered state of mind. Questions of public policy, he reasons, are only of value when projected upon a background of a given state of facts. Any change or evolution in the course of time of the factual background may render previous public policies valueless. At such a time the old public policy may be found to have lost its efficacy and must be re-shaped to fit changed conditions. When we come to our present problem, we must settle in our mind whether it is the present policy of the law that the citizen should be wronged, rather than that public governments should suffer inconvenience. This much may be noted without proof:-If the interference with the business of a public body is so great, it must be indeed so much more so in the case of private corporations such as railroads and other public utilities operating in the public interest, who are now generally subject to the process of garnishment. And it is certainly to be noted that in the states where garnishment of governments is permitted by statute, the interference with governmental business has been reduced to a minimum by slight procedural changes. For example, Colorado permits the garnishee to answer by mail ${ }^{15}$ in Nebraska the officer whose duty it is to pay over funds may answer in person, in writing, or by mail:;6 while in Minnesota it is provided that if the summons against a municipal official is returnable in some other city, village or municipality, the officer need not appear in person, but that a referee may be appointed to take the disclosure. ${ }^{17}$

The generally held notion that the public business would be seriously impaired is attacked by Montana's Justice De Witt in a case where he

${ }^{44}$ Van Cott v. Pratt, II Utah 209, 213, 39 Pac. 827 (1895).

${ }^{5}$ Colo. Laws I927, 374. $\quad{ }^{26}$ Neb. L. I925, 214. $\quad{ }^{17}$ Mason's Minn. Stat. I927, § 9364. 
construed the word "person" in a garnishment statute to apply to "bodies politic and corporate." ${ }^{\prime 8}$ He says:

We cannot agree that there is any reason why the great public duties of a county need be imperfectly performed, or that its business is in any danger of derangement, if it be compelled, by process of a court, to pay the salary of a servant to that servant's creditors. The county has no suit to defend, no counsel to employ, no witnesses to collect and pay. It has no burden cast upon it, and no duty to perform, except to act as temporary stakeholder, to await the determination of a court, in an action in which the county has no interest. The argument of public policy as to inconvenience to the county and its officers does not reach our mind with sufficient force to impair another view of law and of right that is recognized throughout the civilized world; that is, that debtors should pay their debts. ${ }^{\text {I9 }}$

The common law principle as thus evolved by the courts has been considerably modified in recent times. In twenty-four states, garnishment is now permitted to a greater or lesser extent against employees of the state, or against employees of municipal and quasi-public bodies in the states. In twenty-one of them the legislature has settled the matter by enacting legislation on the subject, while in three others this has been accomplished by construction of existing law. These statutes were all enacted within the present century; the earliest of them seems to be Montana's in Igor, and the most recent that of Kansas in I933. In general these statutes cover the same field. Some of them subject only the salaries of employees to garnishment, while others extend to "all credits and personal property" due the employee. Most of the states enacting such legislation are located in the west or middle west, with a few in the south. In two of them (Idaho and Nevada) employees of the state do not come under the statutes; while in other states (South Dakota and New York) only state employees are subject to its terms, while municipal employees are not. A summary of the existing law on the subject is appended in an accompanying table. These states which have held that garnishment of public employees is not against public policy, have extended this principle only to employees of municipal corporations, preferring to wait for the legislature to act in the case of employees of the state. On the other hand, in those states which adhere to the common law rule against such garnishment, though some of the decisions are quite recent, many of them date back scores of years. In Illinois, for instance, the last Supreme Court decision on that point is as far back as $1872 ;^{20}$ Indiana's last holding on this matter is dated $1876 ; 2 \mathrm{in}$ Vermont no case has been decided on exemption of public employees since $1834 ; ;^{22}$ and Connecticut's last case in point was handed down in $1835 .{ }^{23}$

${ }_{18}$ Waterbury v. Board of Commissioners, Io Mont. 515, 520, 26 Pac. 1002 (I89I).

${ }^{29}$ ro Mont. 515, 523, 26 Pac. I002, I004 (I89r). $\quad{ }_{21}$ Wallace v. Lawyer, 54 Ind. 50r (1876).

${ }^{20}$ Triebel v. Colburn, 64 Ill. 376 (1872).

2 Bradley v. Richmond, 6 Vt. I2I (1834).

${ }^{23}$ Stillman v. Isham, II Conn. I24 (I835). 
We think the time has come [says the author of a note in $96 \mathrm{Am}$. St. Rep.] when this question should be re-examined in the light of modern conditions. Society has changed wonderfully since the days when the foundation of the doctrine of exemption of salaries was laid. And if the question should be re-examined, perhaps after all it would be concluded that the public service would not suffer, but would be benefited, by holding officers to the same accountability for their debts as other people are held to. ${ }^{24}$

It would certainly be a fruitful task for some competent agency to make an actual statistical study, in cities where garnishment of salaries is now permitted, of the actual extent of its interference with the public business. A grant of federal funds for this work would be highly worth while. Perhaps when the courts are confronted with the facts of the actual experience of jurisdictions where garnishment is now permitted, their conception of the public policy involved would undergo a radical change. If we are to continue our present policy of making governmental employees immune from accountability for their debts, we must be really sure that any other policy would be "at all times found embarrassing, and . . . f fatal to the public service." 25

SUMMARY OF STATE LAWS IN FORCE, JULY, 1935, ON GARNISHMENT OF PUBLIC EMPLOYEES

\begin{tabular}{|c|c|c|}
\hline State & $\begin{array}{l}\text { Date Original } \\
\text { Law Enacted }\end{array}$ & Sections Authorizing \\
\hline 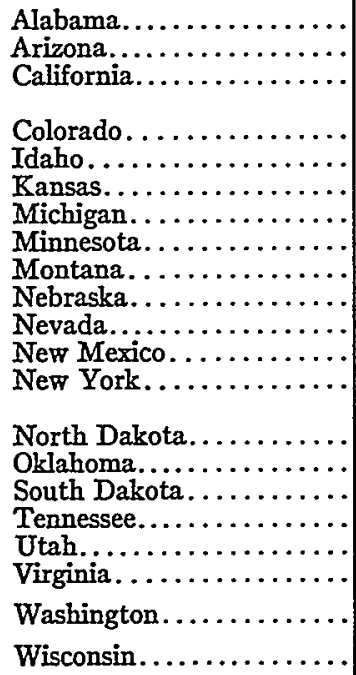 & 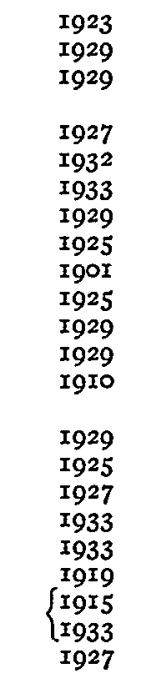 & 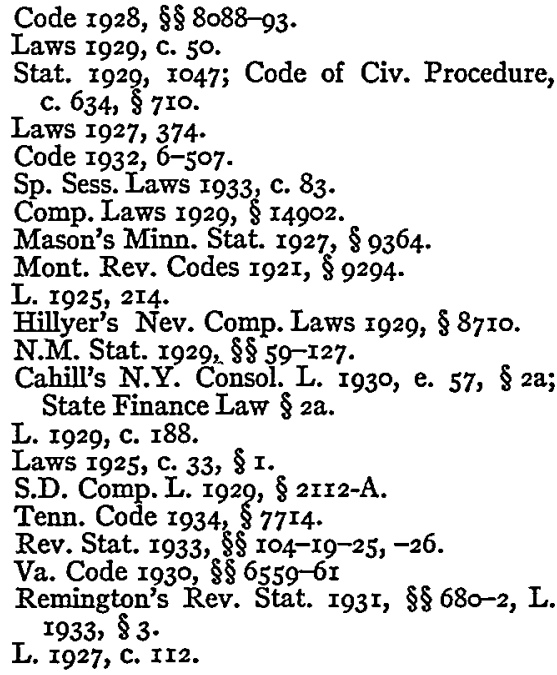 \\
\hline
\end{tabular}

${ }^{24} 96$ Am. St. Rep. 443, 446 (Ig04).

25 Buchanan v. Alexander, 4 How. (U.S.) 20 (I846). 